Jurral PenddkanBabsadenSastra, V dume12, Nomr 1, April 2012

\title{
PEMAKIAN BILINGUALISME DALAM INTERAKSI SISWA DI KELAS RENDAH DI MADRASAH IBTIDAIYAH NEGERI SINGARAJA BALI
}

\author{
Siti Rahmi \\ FKIP Universitas Nahdlatul Wathan Mataram, NTB \\ Korespondensi: Jln. Kaktus 1-3 D asan Agung Mataram \\ pos-el: rahmi_mataram@yahoo.co.id
}

\begin{abstract}
Abstrak
Pemakaian Bilingualisme dalam Interaksi Siswa di Kelas Rendah di Madrasah Ibtidaiyah Negeni Singaraja Bali. Tulisan ini mengungkapkan realitas dari implikasi bilingualisme dalam pendidikan dasar. Konteksnya tidak hanya memperhatikan pembelajaran bahasa, tetapi terhadap pendidikan dalam arti luas. Hal ini karena bilingualisme <<memaksa >> para guru untuk mempertimbangkan pengajaran bahasa dalam pembelajaran di kelas. Umumnya, siswa dari Madrasah Ibtidaiyah Negeri Singaraja Bali -Sekolah Dasar Islam- memiliki latar belakang bahasa Indonesia (L1). Bahasa Indonesia digunakan dengan berbagai dialek dan kosa kata bahasa Bali. Penggunaan bahasa Indonesia sebagai bahasa sehari-hari mereka disebabkan orang tua mereka berasal dari latar belakang lingkungan dan masyarakat multi-etnis. Orang tua mereka adalah generasi keempat dan kelima dari nenek moyang mereka, dan hampir tidak menggunakan bahasa asli mereka dalam ranah keluarga. Para keluarga migran ini sebagian besar adalah pedagang, buruh, dan beberapa dari mereka adalah PNS. Bahasa Bali, sebagai L2 diperoleh dalam lingkungan sosial terutama di sekolah menengah. Implikasi dari Bahasa Indonesia sebagai bahasa pengajaran lebih "mendidik-akomodatif", disesuaikan dengan latar belakang bahasa siswa dan tingkat perkembangan bahasanya.
\end{abstract}

Kata kunci: bilingualisme, implikasi, bahasa, pembelajaran

\begin{abstract}
Bilingualism Implications in Primary Classroom Interactive Students of Madrasah Ibtidaiyah N egen Singaraja Bali. This paper reveals the reality of these implications. Its context does not concern only in the language learning, but into the education in broadest sense also. It is because bilingualism "force" teachers to consider language teaching in the classroom instruction. Generally, students of Madrasah Ibtidaiyah Negen Singaraja Bali-as an Islamic Primary Schoolhave Indonesian language background (L1). Indonesian language used with various dialects of Balinese language and its vocabulary. The use of Indonesian as their everyday language is caused their parents from neighborhood background and the multi-ethnic milieu. Their parents are fourth and fifth generation of their forefather, and almost had not used their native language in family domain. The migrant families were mostly traders, laborers, and some of them are civil servants. Balinese language, as L2 acquired in social domain especially in secondary scholl. The implication of Indonesian as language teaching more "educative-accommodative"; adjusted by students's language background and their level of language development.
\end{abstract}

Keywords: bilingualism, implication, language, learning

p-ISSN 1412-0712 | e-ISSN 2527-8312 